\title{
Salt ingestion caves
}

\author{
Charles A. Lundquist ${ }^{1}$ and William W. Varnedoe $\mathrm{Jr}^{2}$
}

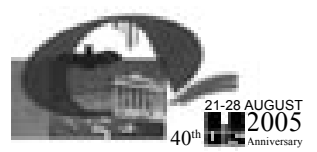

Paper presented during the 14th International Congress of Speleology, Kalamos (Greece) 21-28 August 2005.

\begin{abstract}
:
Lundquist C. F. and Varnedoe W. W. Jr. 2005. Salt ingestion caves.

International Journal of Speleology, 35 (1), 13-18. Bologna (Italy). ISSN 0392-6672.
\end{abstract}

\begin{abstract}
Large vertebrate herbivores, when they find a salt-bearing layer of rock, say in a cliff face, can produce sizable voids where, over generations, they have removed and consumed salty rock. The cavities formed by this natural animal process constitute a unique class of caves that can be called salt ingestion caves. Several examples of such caves are described in various publications. An example in Mississippi U.S.A., Rock House Cave, was visited by the authors in 2000. It seems to have been formed by deer or bison. Perhaps the most spectacular example is Kitum Cave in Kenya. This cave has been excavated to a length over 100 meters by elephants. An ancient example is La Cueva del Milodon in Chile, which is reported to have been excavated by the now extinct milodon, a giant ground sloth. Still other possible examples can be cited. This class of caves deserves a careful definition. First, the cavity in rock should meet the size and other conventions of the locally accepted definition of a cave. Of course this requirement differs in detail from country to country, particularly in the matter of size. The intent is to respect the local conventions. The characteristic that human entry is possible is judged to be a crucial property of any recognized cave definition. Second, the cavity should be significantly the result of vertebrate animal consumption of salt-bearing rock. The defining process is that rock removed to form the cave is carried away in the digestive track of an animal. While sodium salts are expected to be the norm, other salts for which there is animal hunger are acceptable. Also some other speleogenesis process, such as solution, should not be excluded as long as it is secondary in formation of a cave in question.
\end{abstract}

Keywords: Cave, Salt, Ingestion, Sodium, Animals

Received 13 October 2005; Revised 3 November 2005; Accepted 4 November 2005

\section{BACKGROUND CIRCUMSTANCES}

From the dawn of civilization, humans have observed that some animals congregate at "salt licks" and that these are auspicious sites to hunt these animals. Starting from such ancient fundamentals, Derek Denton (1982), in his monumental tome, Hunger for Salt, An Anthropological. Physiological and Medical Analysis, reviews all aspects of animal and human need for salt. In his Introduction he stresses "the role of sodium as the principal cation of the circulating blood and tissue fluids of animals. Sodium predominates over the other constituents of tissue fluids such as potassium, calcium, magnesium, phosphate, bicarbonate, sulfate and chloride". Denton observes that in large areas of the continents, there

\footnotetext{
${ }^{1}$ University of Alabama in Huntsville, 214 Jones Valley Drive,
} Huntsville, AL 35802, U. S. A. <lundquc@email.uah.edu>

\footnotetext{
${ }^{2}$ Huntsville Grotto of the National Speleological Society, 5000 Ketova Way, Huntsville, AL 35803, U. S. A.

<billvar@comcast.net>
}

is very little sodium, as a result of meteorological processes. Sodium content in plants is accordingly very low. This creates an evident evolutionary advantage that accrues to animals that are able to detect salt in geological circumstances and ingest it. The animals in greatest need are the herbivores because of the low sodium content of plants. Carnivores obtain the bulk of their required salt from the flesh of the animals they eat. Large vertebrate herbivores, when they find a salt-bearing layer of rock in a cliff face, can over generations produce sizable voids where they have removed and consumed salty rock. These cavities that humans can enter can have the characteristics of a cave, as defined locally.

This class of caves, which is the subject of this paper, requires a definition. First, the cavity in rock should meet the size and other specifications in the locally accepted definition of a cave. This requirement can differ in detail from country to country and from state to state. The intent is to accept the local conventions. The characteristic that human entry is possible is a crucial property of any recognized cave definition. 
Second, the cavity should be significantly the product of vertebrate animal consumption of salt-bearing rock. The defining process is that rock removed to form the cave is carried away in the digestive track of an animal. While sodium salts are expected to be most common, other salts for which there is animal hunger are acceptable.

Also some other cave formation process, such as solution, should not be excluded as long as it is secondary in formation of a cave in question. The authors recognize that these two requirements are somewhat arbitrary, but the scope of discussion needs to be constrained.

Many speleological, scientific and popular documents contain descriptions of caves that seem indeed to satisfy the definition above for inclusion in this study. For example, Denton, in his chapter "The natural history of sodium deficiency and salt appetite in wild animals", gives a rather comprehensive global review that includes references to a number of animal produced caves.

This paper is based largely on such published documents having many forms and purposes. It is often unclear whether a cited cavity or cave meets the stated conditions to be included in this paper. Some judgment must be exercised in placing a candidate either on an accepted list or in a tabulation of potential cases for which data is insufficient to make an informed determination.

A location illustrating this situation is Cambodia (Wharton, 1957). A typical Cambodian salt lick is described as a stinking quagmire of mud with thousands of animal tracks, to one side of which is the freshly exposed stratum with large holes several feet in diameter eaten out of it. An examination in the field might show that some specific examples of these holes deserve to be called caves. Similarly, a review, Natural Game Licks in the Rocky Mountain National Parks of Canada, mentions a few sites that have cavities that may qualify as caves (Cowan \& Brink, 1949). The Glacier Lake lick in Banff Park has the description "White cliffs overlooking Howse River at its union with Glacier Lake Creek are deeply excavated by goats". A lick in Jasper Park is "Athabaska Falls - A large white-earth cliff on the east bank of the Athabaska River, twenty-three miles south of Jasper, serves a population of twenty or more goats from nearby Mount Kerkealin. Holes eaten into the cliff face are large enough to accommodate adult goats."

Although not a prime subject here, it is worth noting that the animal consumption can be an interesting secondary process in caves of other principal origins. Animals may modify wall characteristics locally or perhaps even create a room off a larger cave. A potential example of this sort is Deer Cave in Mulu Mountain, Sarawak.

The cave is so named because deer come into the cave to lick salt-bearing rocks (Tsen, 1993). Since this cave contains one of the largest cave passages known to man, it is certainly not the result of the deer visits. Still, the deer may have left their mark in localized areas.

\section{CASE STUDIES}

\section{Altai Mountain Caves, Asia}

The concept of speleogenesis by salt ingestion by animals is not recent For example, in 1826, Carl Friedrich von Ledebour published a commentary on his travels through the Altai mountains of central Asia (Ledebour, 1826). His report is quoted and discussed in an 1873 paper by G. Bunge (Bunge, 1873). Ledebour describes an occurrence of shale on the lower elevations of a mountain that bordered one side of the very flat, swampy, and somewhat wide valley of the Kan River. This site was near the confluence of the Kan and Tscharnsch Rivers. He reports that the stone, (shale) that forms the mountain appeared to contain a significant amount of salt, and questioned whether it might be epsom salt. He observed that "all livestock of the Kalmucks find this rock, which gives the mountain an ash-gray appearance, very desirable and consume it in not small amounts, so that one not infrequently finds grottoes built in this way". He continues that these animals, and even wild ones, frequently visit this mountain to eat the salty, easily broken shale. It seems reasonable to conclude that these grottoes must have some appreciable size to have warranted mention as grottoes by von Ledebour.

\section{Rock House Cave, U.S.A.}

Rock House Cave in Mississippi was visited by the authors. The animal origin of small caves in Rankin County was recognized by Hilgard (1860) in his "Report on the Geology and Agriculture of the State of Mississippi". Boughman (1971) discussed Rock House Cave as an example of such a cave. The cave was brought to the attention of the NSS membership by an article in the NSS News (Carey \& Middleton, 1973). The cave is situated in a small bluff. Its entrance is 10 feet wide, inside it widens to about 20 feet and goes

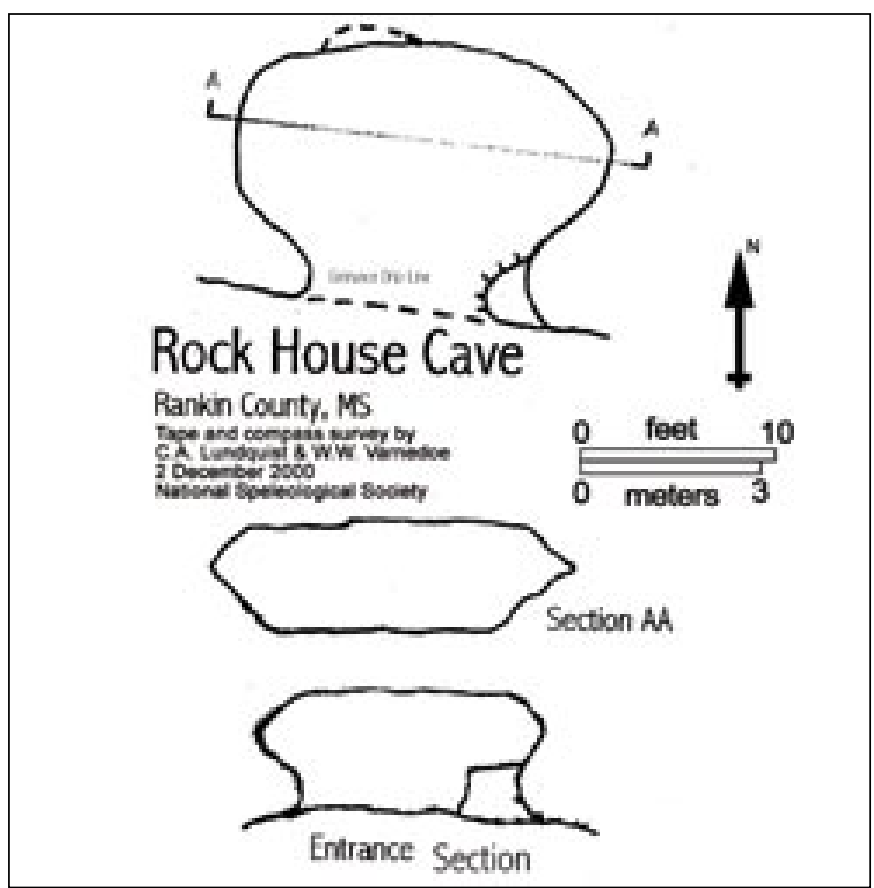

Fig. 1. Plan map of Rock House Cave, Mississippi, USA. Survey by the authors. 


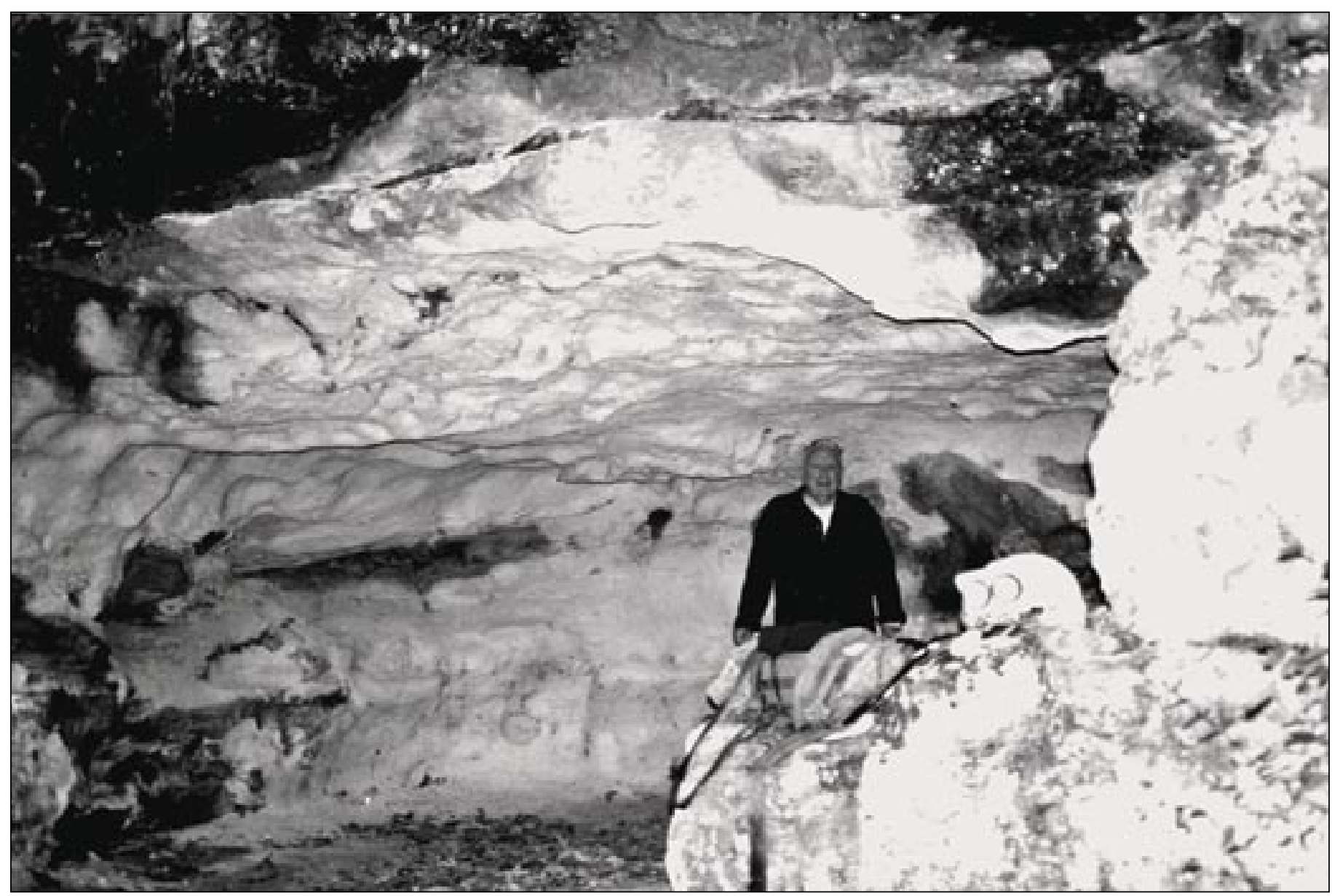

Fig. 2. Entrance to Rock House Cave, Mississippi, C. A. Lundquist on right. Photograph by W.W. Varnedoe, Jr.

into the bluff 15 feet. The roof is just high enough for a person to stand.

The cave has been enrolled as MS 21 in Caves of Mississippi, (Knight, Irby \& Carey, 1974).

The formation from which animals have ingested the salt-bearing rock is soft, fine-grained sandstone of the Cataboula Formation. An analysis by Francis L. Schmeh found that the rock contains from 0.52 to 2.12 percent $\mathrm{NaCl}$ (Boughman, 1971). There appears to be no evidence of water solution contributing to the cave size. The walls of the cave have a uniform sandy texture that one can accept as being formed by licking. In the vicinity of Rock House Cave are other bluff salt lick sites not yet developed into caves. Hilgard says "in some instances the cattle have eaten caves into the hillsides". However, we judge that originally deer or perhaps also bison are more probably responsible for the cave than cattle.

\section{Kitum Cave and Similar Caves, Kenya}

Kitum Cave is the best known of the group of similar caves found on Mount Elgon on the border of Kenya and Uganda. Mount Elgon is a now dormant volcano that rises to 4,321 meters and is built up largely from soft agglomerates solidified from massive pyroclastic flows. Interspersed between the beds of agglomerates are thinner layers of lava flows, which make up about $1 \%$ of the mountain. As precipitation runs off the mountain, the lava flows are more impervious to water and resistant to erosion. Hence, where the edge of a lava flow or of a denser agglomerate layer is exposed on the mountain side, cliffs form in the softer agglomerates below the exposed impervious, caprock edge. At least many-tens of caves are formed in these cliff faces, with the lava or other impervious caprock layers providing solid roofs for the caves. Often there is a waterfall off the ledge above the cave entrance. Most of this water goes on down the mountain slope, but some water drains into the cave, forming shallow stagnant pools. Typically, there are no active streams flowing out of the caves. The presence of some ground water seepage through the agglomerate layers is demonstrated by its generation of the unusual mineralogy that is found in the cave (Forti, 2005). Kitum is a typical cave of this sort on the Kenya side

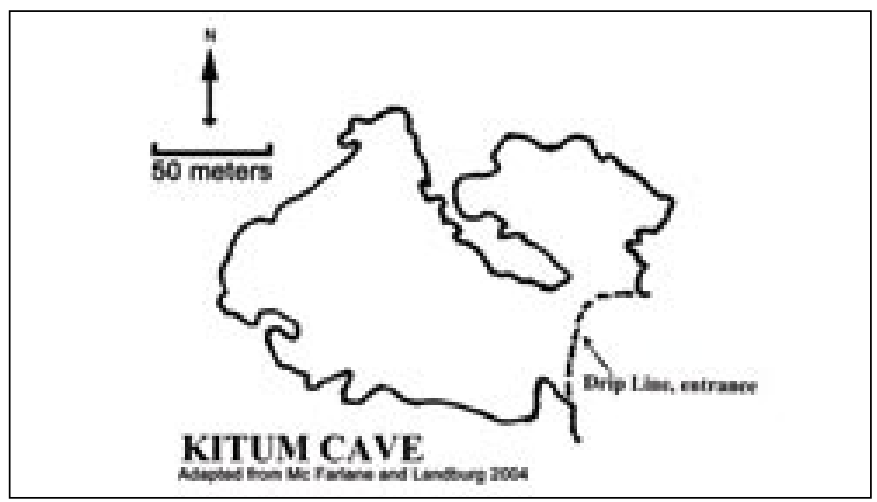

Fig. 3. Plan Map of Kitum Cave, adapted from McFarlane \& Lundburg (2004). Note the lobate shaped walls formed by the elephant activity. 
of Mount Elgon. It is one of four similar caves open to the public in Kenya's Mount Elgon National Park.

The agglomerates have a small fraction of sodium sulfate, also known as Glauber's salt, incorporated in them. This is an attractive source of sodium for the wild herbivores of the region, particularly elephants. Elephants, buffaloes, antelopes and even monkeys are observed to be regular visitors to the caves in the agglomerates, where they ingest quantities of the soft rock. In Kitum Cave, the rock face now worked by the elephants is some 160 meters into the mountain from the entrance. The elephants loosen the rock with their tusks, pick up the loose pieces with their trunks, put the pieces in their mouths and crush them with their teeth. This process has been recorded by infrared video and was widely viewed on cable television, (Mutual of Omaha, 2004). Other animals lick the rock face or eat small fragments left by natural rock falls or by the elephants. These circumstances on Mount Elgon are described by a rather extensive literature, going back to an early observation by Hobley (1897). Other significant background references are Perkins (1965) and Sutcliffe (1973) which also contains a large list of references.

Given the circumstances for the Mount Elgon caves, there is some uncertainty found in the literature as to the predominant process that has formed the caves. Some authors favor an undefined solution and erosion process related to ground water sapping or to the waterfalls at the entrances, perhaps during heavy rain or flooding. A thoughtful examination of this question has been provided by Ian Redmond (1984). He spent much of five months camping in a safe spot in Kitum Cave observing and photographing principally the elephants. Importantly, he collected elephant droppings outside the cave to confirm that significant quantities of insoluble rock are removed by the elephants. He then offers the following analysis: "The volume of Kitum cave is on the order of 1.3 million gallons. [about 5 million liters.] If, for the sake of conservative argument, we suppose that elephant excavations average just one quart per week, it would have taken only 100,000 years for them to dig Kitum. ... the theory of elephant speleogenesis is entirely plausible."

In 2003, Donald McFarlane and Joyce Lundberg (2004) made an eight-day field study at Mount Elgon National Park, with the "principal objective to undertake a detailed, quantitative investigation of the relative contributions of solution, collapse, human mining and elephant geophagy to the formation of the larger Mount Elgon Caves". They suggest multi-step mechanisms and a sequence for cave development. First, a cliff forms where water falling off a caprock layer erodes away softer underlying material. Second, clay sized material from a layer at the floor of the cave is removed by groundwater sapping. Additional mass is removed by animal excavation. Third, collapse of overlying beds makes piles of broken material which are removed by action of water and animal geophagy. Fourth, the cave enlarges by the continuation of these processes. These authors do not estimate the relative quantities of mass removed by action of water and by animals, but they surely recognize that animal consumption is a significant process.

Other valuable insights into the Mt. Elgon caves come from A.J Perkins and Renshaw MitfordBarberton, who both have lived on Mt. Elgon for many years (Perkins, 1965). They "have examined over thirty caves on the East and South Eastern slopes of Mount Elgon at altitudes varying from 6,000 feet to 12,000 feet [1800 meters to 3700 meters] and have found that with very rare exceptions, they all conform to one type". They conclude that all must have been formed by a similar agency. They observe that the entrances to the caves are invariably wider than they are high and that water often falls over the lip of the lava caprock above the cave entrance. In some cases, particularly during heave rainfall, some of this water flows back into the cave, temporarily flooding it. In normal circumstances, however, the caves only have small pools of water in them and the water is entirely static. Typically, there are no streambeds in the caves. A common feature in most of the larger caves is the quantity of dung deposited by beasts which have come to the caves from time immemorial to lick or otherwise consume the agglomerate walls. Traces of elephants using the caves are most common, and their tusk marks are clearly recognizable where they have gouged the rock.

In summary, there is ample evidence that animal consumption of material from the cave walls and from breakdown surfaces removes significant quantities of rock. The lack of permanent streams out of the caves precludes removal of mass by that mechanism. That some material is dissolved or washed out during flooding episodes is clear, but the quantity is difficult to estimate. One could perhaps argue that if mass removal during flooding episodes was dominant, then the many tusk marks on exposed surfaces should be removed, and only a few most recent marks should remain. A compelling case is elusive for dominance of either water processes or alternatively of animal processes in forming the Mt. Elgon caves. However, the authors tend to agree subjectively with Redmont's belief that animal consumption of salt bearing rock is the primary process.

\section{Milodon Cave, Patagonia, Chile}

Milodon Cave is presently a Chilean National Monument: La Cueva del Milodon, near Puerto Natales, Patagonia, Chile. La Cueva del Milodon, was explored in February, 1895 by Herman Eberhard, who had established a ranch near Puerto Consuelo on Last Hope Sound in Patagonia (Chatwin, 1977). The entrance was visible from his establishment. A year later, Dr. Otto Nordenskold, a Swedish explorer, visited the cave and found some large bones. These were eventually identified as bones of an extinct ground sloth, the milodon, unique to the Americas. The species of milodon native to Patagonia is the Giant Ground Sloth, Mylodon darwini, whose remains were in the cave. In about 1899, a Swedish archaeologist, Erland Nordenskjold, undertook a dig in the cave. 
He is reported to have found three stratified levels with milodon remains only in the lowest level.

A second contemporary digger, Dr. Hauthal of La Plata, uncovered a layer of well preserved sloth dung, mixed with leaves and grass. More recently, Bruce Chatwin (1977) visited the cave and assembled the

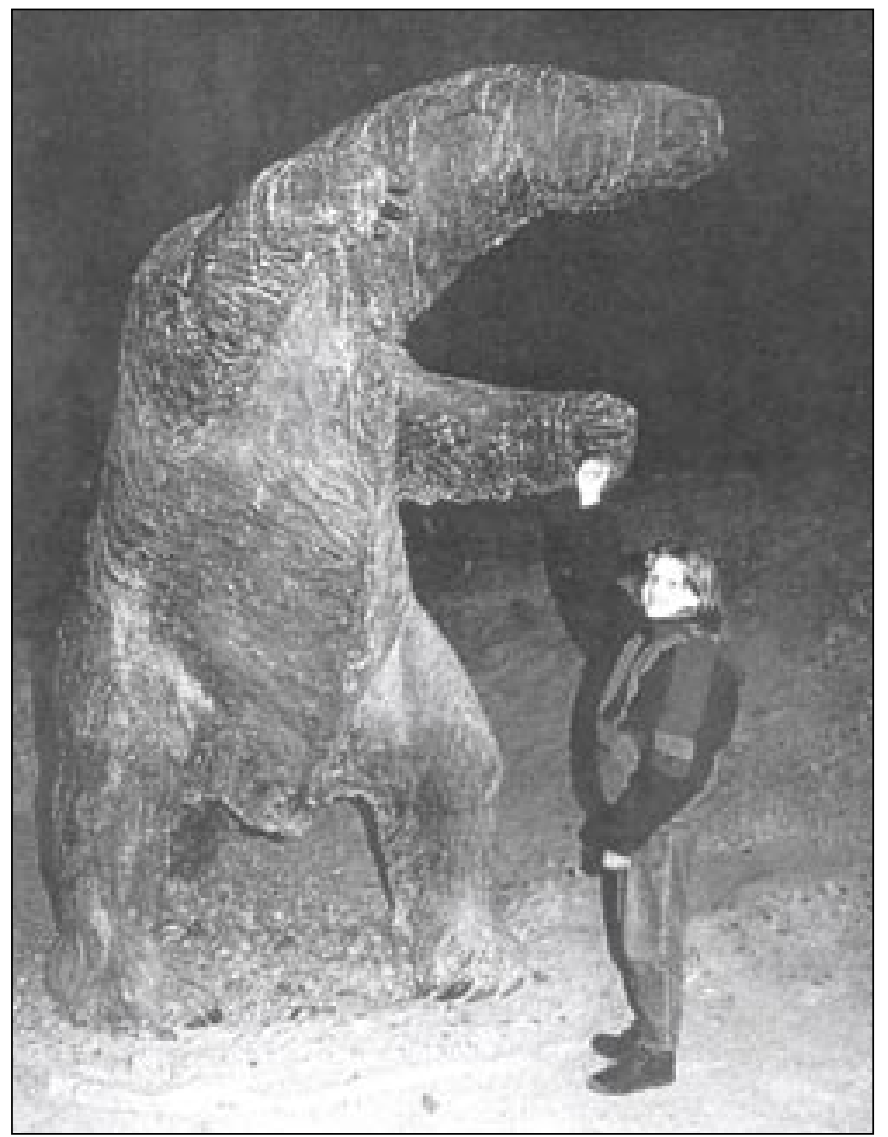

Fig. 4 - Model of a Milodon illustrating the size of the extinct animal. account of its history sketched above. The region has complex geology, with numerous volcanic deposits. From his visit, Chatwin relates that the cave mouth is four hundred feet wide in a cliff of gray conglomerate Fig 5. The side walls glittered with salt encrustation and "animal tongues had licked the back wall smooth". He notes that "the floor was covered with turds, sloth turds, outsized black leathery turds, full of ill-digested grass". The cave was very dry, as it would have to be for the observed material to have survived.

A sign at the Monument attributes the formation of the cave to melting glaciers. A diagram on this sign shows the cave to be a sort of sea cave at the surface of a melting glacier. This argument seems very weak and does not fit the surrounding terrain. But the evidence that Milodon Cave has a salt ingestion origin is only suggestive, not conclusive. The conglomerate rock forming its walls apparently has a salt content of some kind, rather like Kitum Cave. Chatwin believed that the back wall showed evidence of animal licking. The first users of the cave seem to have been the milodons, Fig. 4. Hence creation or at least enlargement of the cave by milodons ingesting rocks is quite plausible, if not certain.

\section{CONCLUSIONS}

The authors suspect that salt ingestion caves are more prevalent than might be thought. The principal examples we identified seem to be relatively well known, and the literature on them goes back into the 1800s. We doubt that Rock House Cave in Mississippi is the only U.S. example since salt bearing-rock occurs widely. Of course, we have probably missed some examples in the U.S. literature. Some may be discussed in documents not usually read by the

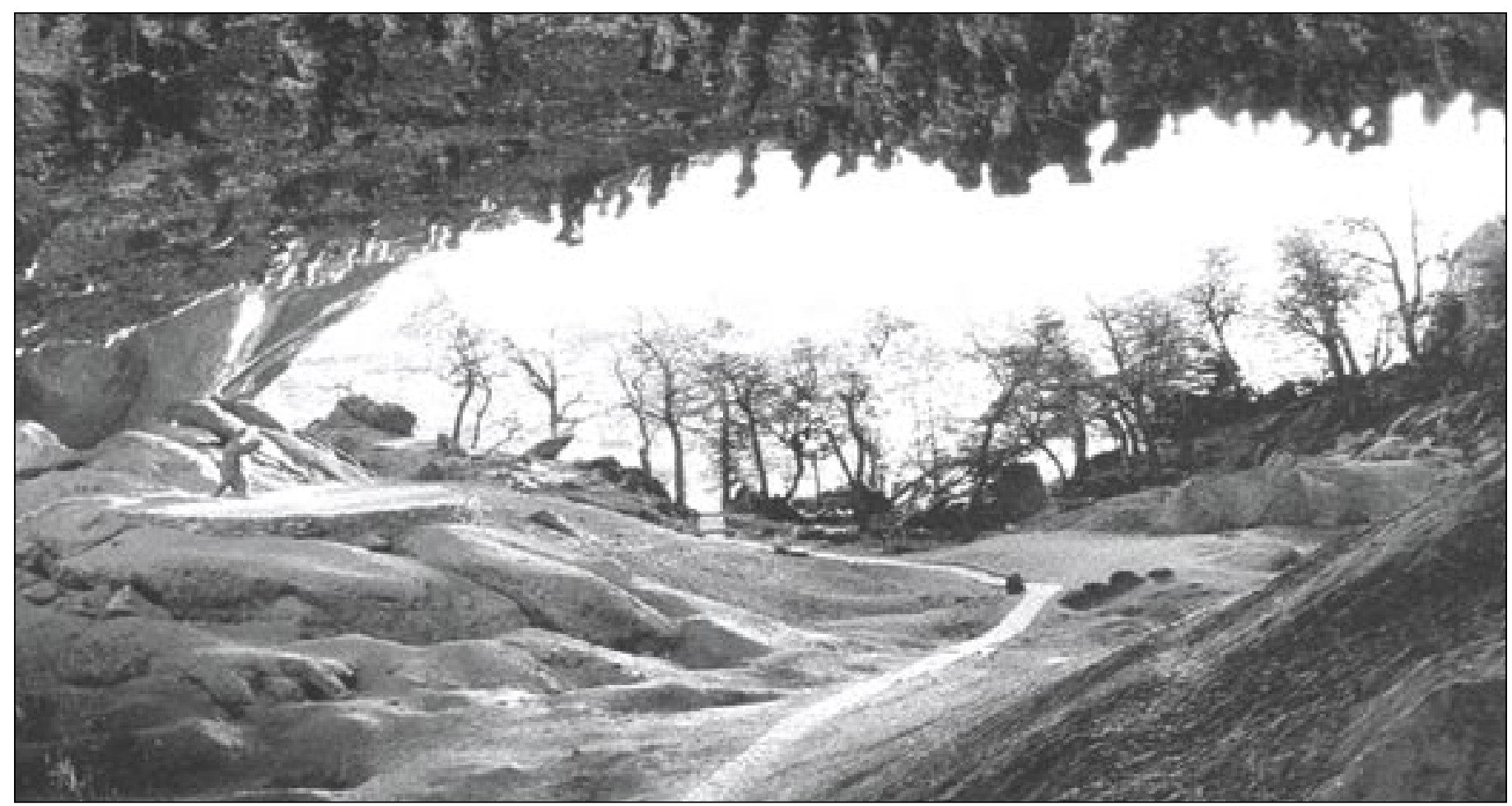

Fig. 5. Entrance to Cueva del Milodon, Chile. Image from commercial post card. The Milodon of Figure 4 is on a flat platform on the left. Note the encrustations on the roof. 
caving community.

Other salt ingestion caves probably exist whose origin has not been recognized or recorded. We hope that this rather limited study will promote more awareness of this possible cave origin.

The authors further suggest that speleogenesis by salt ingestion offers many fascinating opportunities for scientific investigations. Clearly, for example, the studies on the Mount Elgon, although valuable, have been very limited in scope. A simple automatic camera system at Rock House Cave might record with certainty what animals currently frequent that site. An examination of the preserved droppings in Milodon Cave could reveal whether they contain undigested rock residue as evidence of rock ingestion by the milodons. The possible topics are numerous.

Finally, we re-emphasize that rock ingestion by animals is an old observation. While we have not tried to search the literature of antiquity, we did note one ancient citation (Aristotle, ca $350 \mathrm{BC}$ ). Aristotle wrote about elephants "And if it eats earth it becomes weakly, unless it eats continually; if it does so continually, it is not harmed. It also swallows stones sometimes". This passage must be a reference to elephants eating saltbearing earth and rocks.

\section{ACKNOWLEDGEMENTS}

The authors wish to acknowledge essential help by the librarian at the NSS Library in Huntsville, and by the Interlibrary Loan services of the Salmon Library at the University of Alabama in Huntsville.

\section{REFERENCES}

Aristotle, ca 350 BC - History of Animals book VIII 605 23 (See for example the translation by D. M. Balme, Harvard University Press Vol XI p 191, Cambridge, 1991).

Boughman W. T., 1971 - Rankin County Geology and Mineral Resources. Mississippi Geological, Economical and Topographical Survey Bulletin 115: 54-55.

Bunge G., 1873 - Uber die Bedeutung des Kochsalzes das Verhalten der Kalisalze im menschlichen Organismus.
Zeitschrift fur Biologie 9: 104-143.

Carey S. D. \& Middleton A. L., 1973 - The Rock House-An Unusual Mississippi Shelter Cave. NSS News. 31: 198.

Chatwin B., 1977 - In Patagonia. copyright 1977, pub, by Penguin Books, 1988.

Cowan McT. \& Brink V.C., 1949 - Natural Game Licks in the Rocky Mountain National Parks of Canada. Journal of Mammalogy 30(4): 379-385.

Denton D., 1982 - The Hunger for Salt. An Anthropological, Physiological and Medical Analysis. Springer-Verlag, Berlin Heidelberg New York.

Forti, P., 2005 - Genetic Processes of Cave Minerals in Volcanic Environments: an overview. Journal of Cave and Karst Studies 67(1): 3-13.

Hilgard E.W., 1860 - Report on the Geology and Agriculture of the State of Mississippi. Mississippi State Printer, Jackson, MS.

Hobley C.W., 1897 - Notes on a journey round Mount Massawa or Elgon. Geography Journal 9: 178-185.

Knight E. L., Irby B. N. \& Carey S., 1974 - Caves of Mississippi. Pub University of Southern Mississippi, Hattiesburg: 31.

McFarlane D. A. \& Lundberg J., 2004 - Zoogeomorphic Analysis of the Mount Elgon Caves, Kenya. Final Report, May 15, 2004.

Mutual of Omaha 2004 - Mutual of Omaha's Wild Kingdom, Cave Elephants. Video documentary shown on Animal Planet Channel in 2004.

Perkins A.J., 1965 - Some Notes on the Caves of Elgon. Cave Exploration Group of East Africa, Newsletter 3: 21-24.

Redmond I., 1984 - Underground Elephants, Animal Kingdom, 30-37.

Sutcliffe A. J., 1973 - Caves of the East African Rift Valley, Trans. Cave Research Group of Great Britain 15(1): 41-65.

Tsen D.N.C., 1993 - The Show Caves of Mulu. Sarawak. Caxton Printing Sdn. Bhd., Kuala Lumpur, second edition.

von Ledebour C.F., 1826 - Reise durch das Altai-Gabirge und die soongorische kirgisen-steppe. auf Kosten der Kaiserlichen Universitat Dorpat untemommen im jahre 1826. Th 2: 44, Berlin.

Wharton G.W., 1957 - An ecological study of the Kounrey. Monograph No 5, Institute of Science and Technology, Manila. 